\title{
Antifouling coating based on biopolymers (PCL/ PLA) and bioactive extract from the sea cucumber Stichopus herrmanni
}

\author{
Mehrnoosh Darya ${ }^{1 *} \mathbb{D}$, Mehdi Haji Abdolrasouli ${ }^{2}$, Morteza Yousefzadi ${ }^{3}$, Mir Masoud Sajjadi ${ }^{1}$, \\ Iman Sourinejad ${ }^{4}$ and Maaroof Zarei ${ }^{5}$
}

\begin{abstract}
An important challenge to decrease the toxic effects of the common biocides in marine environments and to achieve suitable ecofriendly natural antifouling coatings is to find effective natural antifoulants and efficient biodegradable coatings. In this study, antifouling activities of nine bioactive extracts (non-polar to polar) from different organs of the sea cucumber Stichopus herrmanni were tested against five bacterial strains, barnacle and brine shrimp larvae. The ethyl acetate extract of the body wall showed the highest in-vitro antifouling activity including high antibacterial and anti-barnacle activities and low toxicity against the brine shrimp as non-target organism. Based on these results, $10 \mathrm{phr}$ of the ethyl acetate extract from S.herrmanni was added to different coatings consisting of polycaprolactone (PCL)/polylactic acid (PLA) blends containing various compositions of PLA (0, 10, and 20 wt.\%). Polyvinyl chloride panels were coated with the prepared antifouling coatings and immersed in seawater for three months. Panel coated with PCL 80\% /PLA 20\% containing 10 phr of the antifoulant (panel-5), showed the highest resistance against fouling settlement with fouling coverage of $41.66 \%(P<0.05)$. In addition, the lowest fouling weight was measured in panel-5 as well $(81.00 \pm 9.85 \mathrm{~g})(P<0.05)$. These findings indicate the antibacterial and antifouling potential of semi-polar bioactive extracts from the $S$. herrmanni body wall as natural antifoulants, as well as the enhanced antifouling performance of PCL/the natural antifoulant coatings by adding PLA.
\end{abstract}

Keywords: Antibacterial, Biofouling, Biodegradable, Cytotoxicity, Sea cucumber

\footnotetext{
*Correspondence: mehrnooshd12@yahoo.com

${ }^{1}$ Department of Fisheries, Faculty of Natural Resources, University

of Guilan, Sowmeh Sara, Iran

Full list of author information is available at the end of the article
} original author(s) and the source, provide a link to the Creative Commons licence, and indicate if changes were made. The images or other third party material in this article are included in the article's Creative Commons licence, unless indicated otherwise in a credit line to the material. If material is not included in the article's Creative Commons licence and your intended use is not permitted by statutory regulation or exceeds the permitted use, you will need to obtain permission directly from the copyright holder. To view a copy of this licence, visit http://creativecommons.org/licenses/by/4.0/. 


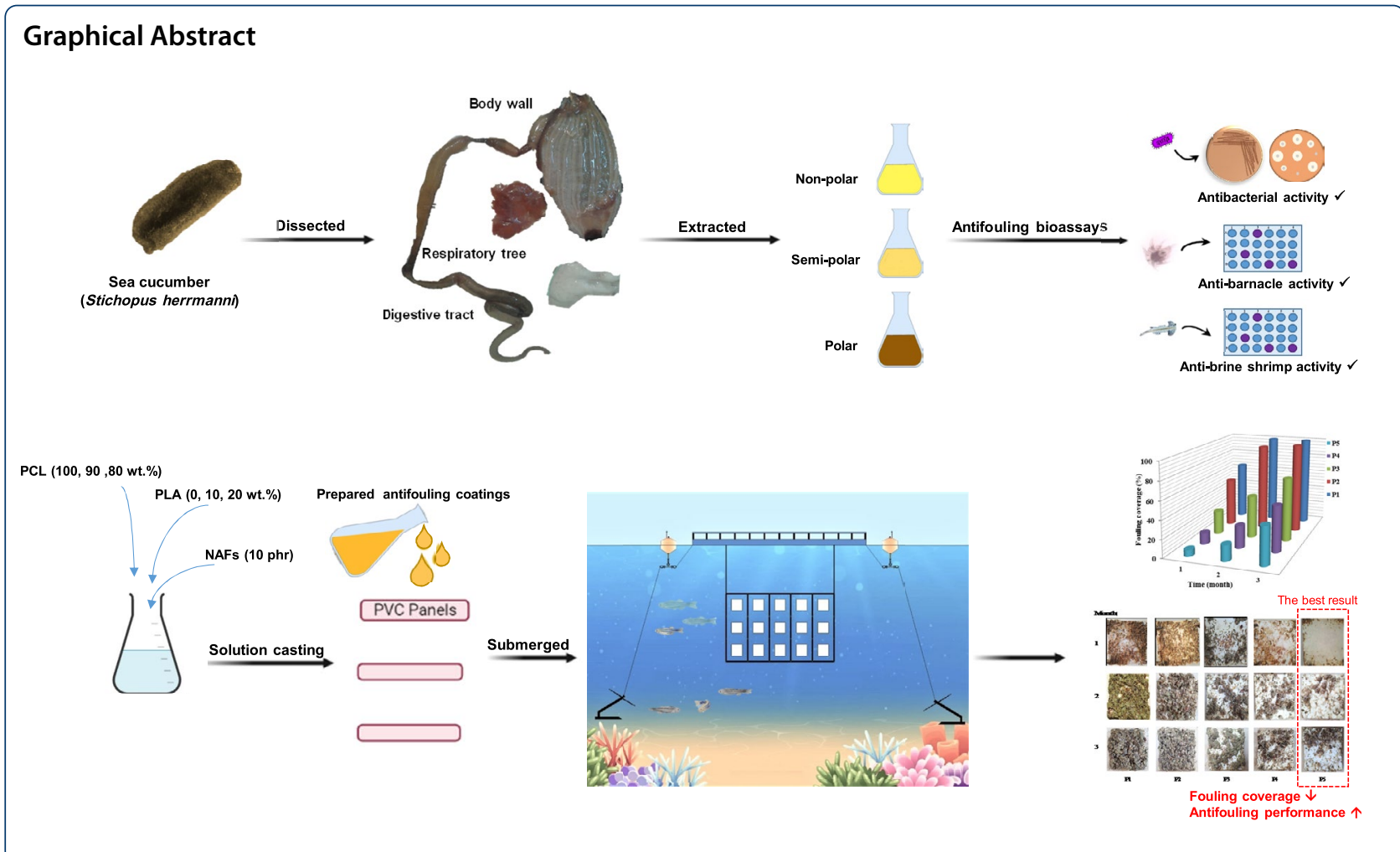

\section{Introduction}

Marine biofouling is a worldwide issue causing an important environmental impact and serious economic and health problems to aquaculture industries and other marine structures (Suresh et al. 2016; Silva et al. 2021). Biofouling directly affects both the aquaculture target species and infrastructure (Fitridge et al. 2012). So far, many strategies have been used in order to control the effects of biofouling, but only a few of them have been practical enough to be widely used for a long time; although they were not harmless. For many years, tributyltin (TBT) and other organotin compounds were the most widely used active agents in antifouling coatings and paints. However, they are harmful to the marine environment because they can leach into the ecosystem and cause harm to non-target organisms (Gittens et al. 2013; Iyapparaj et al. 2013). Accordingly, taking into account the environmental damages and health problems of TBT, International Maritime Organization (IMO) banned its use in September 2008 (Qian et al. 2010).

Following the ban of TBT, metal biocides like zinc and copper have been presented as alternatives to TBT. Copper has been the most used biocide in antifouling coats in recent years (Jerabek et al. 2016), generally with $\mathrm{Cu}_{2} \mathrm{O}$ as the active agent in a polymer matrix (Gittens et al. 2013). Nevertheless, due to serious negative impacts of toxic metal biocides on marine environment and aquaculture species (including bioaccumulation) (Yamada 2007; Bao et al. 2008), there is an urgent need to find nontoxic, environment-friendly and effective antifouling compounds. To discover such proper antifoulants, marine organisms (mostly invertebrates and algae) that typically remain free of foulers have been widely investigated (Qian et al. 2015). These organisms possess secondary metabolites as a chemical defense against biofouling (da Gama et al. 2008; Piazza et al. 2011; Acevedo et al. 2013).

Sea cucumbers are a group of marine benthic invertebrates that produce natural products to defend themselves against external threats. Natural products from Sea cucumbers have been widely investigated for their biological activities such as antibacterial (Mashjoor and Yousefzadi 2017), antialgal, antifungal (Han et al. 2009; Mashjoor and Yousefzadi 2017), antitumoral (Tian et al. 2005) and so forth. Terpenoids are one of the most investigated secondary metabolites of the sea cucumbers, which may be used as new possible antifouling agents (Mert Ozupek and Cavas 2017; Darya et al. 2020). In this regard, triterpene glycosides and saponins derived from the sea cucumbers have been previously considered as suitable candidates for cytotoxic, antimicrobial and antifouling agents (Aminin et al. 2015; Mert Ozupek and Cavas 2017; Bahrami et al. 2018). 
Antifouling agents can be incorporated into the polymer matrix to form a composite coating (Palanichamy and Subramanian 2017). This coating can allow the antifoulant to move gradually from the surface leading to prevent deposition and settlement of the fouler (Azemar et al. 2015). Biobased and/or biodegradable polyesters such as Polycaprolactone (PCL) have the potential to be used as a carrier in marine antifouling composite coatings because they can be decomposed and hydrolyzed by microorganisms or enzymes in the seawater, which results in self-renewing surface (Faÿ et al. 2006). However, the drawback of low rate of degradation can interfere the antifouling ability (Xu et al. 2014; Xie et al. 2019). Some studies have focused on the combination effects between the degradation occurred in composite coatings which can be enhanced through physical and/or chemical modification and allowing the antifoulant to move from the surface. (Yao et al. 2014) developed an antifouling coating based on PCL/nanoclay containing an organic antifoulant (4,5-Dichloro-2-octyl-isothiazolone (DCOIT)). Marine field test showed that the antifouling properties and durability of the surfaces were improved by coating with PCL/nanoclay/DCOIT. Biodegradable PCL based polyurethane coating containing butenolide (which is derived from marine bacteria) was introduced by $\mathrm{Ma}$ et al. (2017). They found that the system had a great antifouling ability lasting for more than 3 months. Chen et al. (2016) prepared PCL/ poly(butylene succinate) (PBS) blends containing $10.0 \mathrm{wt} \%$ of organic antifoulant (4,5-dichloro-2-octyl-isothiazolone) by solution casting for anti-fouling coating. They showed that incorporation of PBS in PCL increased the degradation and releasing rate of the organic antifoulant. It is also interesting to note that polylactic acid (PLA) is a biocompastable and renewable bioplastic which can be used in eco-friendly antifouling strategies (Thouvenin et al. 2003). Azemar et al. (2020) synthesized the block copolymers containing PLA with high antifouling efficiency. Kamtsikakis et al. (2017) used a PLA for encapsulation of three different organic biocides for antifouling application. Chiang et al. (2020) developed a poly(lactic acid)-based polyurethane as a carrier of antifouling coating with optimized release of antifoulant.

In this study, we tried to deal with the biofouling problems in the marine environment in order to decrease the harmful and toxic effects of common biocides. Four different combinations of biodegradable biopolymers were used as coatings and carriers for natural antifoulants. Therefore, we developed biodegradable coatings based on Polycaprolactone (PCL)/Polylactic acid (PLA) containing bioactive compounds extracted from the sea cucumber Stichopus herrmanni, and evaluated their antifouling properties by designing marine field tests.

\section{Materials and methods}

Sea cucumber collection and extracts preparation

Specimens of the sea cucumber S.hermanni were collected by scuba diving from the coastal waters of Hengam island, the Persian Gulf, Iran. After anaesthetizing with magnesium chloride (5\%), the sea cucumbers were washed with fresh water, dissected and their body parts and organs (including body wall, digestive tract and respiratory tree) were separated (Mamelona et al. 2007). Each part was freeze-dried and grinded by an electric grain mill. Afterwards, a serial extraction was done based on the solvent polarity using $n$-hexane (non-polar), ethyl acetate (semi polar) and methanol (polar). About $200 \mathrm{~g}$ of each part was extracted serially based on increasing solvent polarity at $20-23{ }^{\circ} \mathrm{C}$ for $48 \mathrm{~h}$ in darkness. The obtained extracts were filtered through Whatman paper No. 42 for the removal of residual solids and concentrated under reduced pressure to remove the solvents.

\section{Biodegradable polymer materials}

Polycoaprolactone (PCL), Capa 6800 with a melt flow rate of $3 \mathrm{~g} / 10\left(190{ }^{\circ} \mathrm{C}\right.$ at $\left.2.16 \mathrm{~kg}\right)$, was purchased from Perstorp. Polylactic acid (PLA), 2003D with a melt flow rate of $5-7 \mathrm{~g} / 10\left(210{ }^{0} \mathrm{C}\right.$ at $\left.2.16 \mathrm{~kg}\right)$ was supplied by Natureworks LLC.

\section{Antibacterial assay}

Antibacterial activity of the sea cucumber extracts were tested against five Gram-positive/negative bacterial strains: Staphylococcus aureus (ATCC 25923), Micrococcus luteus (ATCC 9341), Escherichia coli (ATCC 25922), Klebsiella pneumoniae (ATCC 10031) and Vibrio harveyi (ATCC 14126); which were obtained from the Pasteur Institute, Tehran, Iran.

Antibacterial screening was done by disc diffusion method (Vanden Berghe and Vlietinck 1991). For stock solutions, $10 \mathrm{mg}$ of each extract of S.herrmanni were dissolved in $1 \mathrm{~mL}$ of DMSO. Mueller-Hinton Agar plates were inoculated with an overnight culture (12-16 h) of each bacterial strain. Whatman paper disks were placed on the agar surface and injected with $10 \mu \mathrm{L}$ of each stock solution extract. Disks injected with DMSO were used as solvent control. Disks with standard antibacterial agent ampicillin (at $10 \mu \mathrm{g} /$ disc) were used as positive control. After the $24 \mathrm{~h}$-long incubation at $37^{\circ} \mathrm{C}$, The diameter of the inhibition zone (IZ) of bacterial growth was measured. No inhibitory effects due to the solvent were observed. The assays were repeated in triplicate.

\section{Anti-barnacle assay}

Barnacles (Amphibalanus amphitrite), sessile marine arthropods, were collected from intertidal zone in Bandar Abbas, Iran. To obtain barnacle larvae, the adults 
were air-drained for 12-14 $\mathrm{h}$ and then immersed in filtered seawater (salinity $35 \%$ and temperature $25{ }^{\circ} \mathrm{C}$ ) (Jun et al. 2008). Nauplius larvae released by adults were transferred to a glass beaker containing filtered seawater until used for the tests. The nine types of stock extracts were dissolved in DMSO and six concentrations were prepared using a serial dilution method. Then, $200 \mu \mathrm{l}$ of each dilution and $1800 \mu \mathrm{l}$ of filleted seawater were pipetted into each well of 24-well plates and 10-20 barnacle larvae were added. The final concentrations of each extract in the wells were: $1,0.5,0.25,0.125,0.062$ and $0.031 \mathrm{mg} / \mathrm{mL}$. The 24-well plates were incubated in darkness at $26 \pm 1{ }^{\circ} \mathrm{C}$ (Venkatnarayanan et al. 2016). After $24 \mathrm{~h}$, the number of larvae that had died or were still alive was counted. Median lethal concentration $\left(\mathrm{LC}_{50}\right)$ values were calculated based on Probit analysis. As a control, the same assay was done without extract solution (extract dissolved in DMSO). In addition, DMSO was used instead of extract solution as a negative control. No inhibitory effects due to the solvent were observed. All concentrations (including controls) were tested in triplicate.

\section{Brine shrimp cytotoxicity assay (as non-target organism)} Brine shrimp (Artemia salina) cysts were purchased and hatched in cone-shaped tanks filled with filtered seawater. Artemia nauplii were hatched at $28 \pm 2{ }^{\circ} \mathrm{C}$ with continues illumination and aeration (Maruthanayagam et al. 2013). Cytotoxicity assay against $A$. salina was also done with the same concentration and control as the barnacle cytotoxicity assay. No inhibitory effects due to the solvent were observed. Similar to the previous experiment, the $\mathrm{LC}_{50}$ was calculated for each extract against the artemia larvae.

\section{Preparation of PCL/PLA/natural antifoulant coating}

The film coatings varying in component ratio were prepared by solution mixing. First, PCL and PLA were dissolved by stirring in chloroform $\left(\mathrm{CHCl}_{3}\right)$ at $50{ }^{\circ} \mathrm{C}$. The weight ratio of PCL to PLA were chosen as 100:0, 90:10 and 80:20. Then $10 \mathrm{phr}$ (part per hundred resin/polymer) of the ethyl acetate extracted-compounds of the body wall from sea cucumber $S$. herrmanni, as natural antifoulant, were added into PCL/PLA solutions while stirred for $2 \mathrm{~h}$. At last, the solutions were coated on polyvinyl chloride $(\mathrm{PVC})$ panels $(10 \times 10 \mathrm{~cm})$ and left to dry at room temperature for 10 days to remove the solvent.

\section{Thermal properties}

Differential scanning calorimetry was performed with a NETZSCH DSC Polyma 214 to study nonisothermal crystallization of the samples at a heating/cooling rate of $10{ }^{\circ} \mathrm{C} / \mathrm{min}$ between $0{ }^{\circ} \mathrm{C}$ and $180{ }^{\circ} \mathrm{C}$. The samples were first heated from $0{ }^{\circ} \mathrm{C}$ to $180{ }^{\circ} \mathrm{C}$ and held for $5 \mathrm{~min}$. Then, they were cooled from 180 to $0{ }^{\circ} \mathrm{C}$. The basic equation for calculating the percentage of crystallinity (Xc) of the hybrid materials via DSC is as follows:

$$
X_{c}=\frac{\Delta H_{c}}{\varphi \Delta H_{100}}
$$

where $\Delta H$ is the crystallization enthalpy of the samples; $\varphi$ is the weight percent of PCL; $\Delta H_{100}$ is enthalpy of crystallization for a $100 \%$ crystalline PCL, which is taken as $136.0 \mathrm{~J} / \mathrm{g}$ in this study (Rezgui et al. 2005).

\section{Marine field antifouling assay}

Panels were set in handmade frames and hung on a cage (marine cage culture system) at a depth of 2-3 m in north of the Persian Gulf in Bandar Gorzeh, Hormozgan, Iran for three months. Frames (including coated and uncoated panels) were immersed vertically at the depth of $2 \mathrm{~m}$ from the water surface and fixed using buoy and anchor. The prepared panels were included panel-1 (P1): uncoated, panel-2 (P2): coated with PCL (100\%), panel-3 (P3): coated with PCL 100\% / antifoulant 10 phr, panel-4 (P4): coated with PCL 90\% /PLA 10\% / antifoulant 10 phr and panel-5 (P5): coated with PCL 80\% /PLA 20\% / antifoulant $10 \mathrm{phr}$. The antifouling performance of polymer coats was evaluated monthly by photograph recording (Chen et al. 2016; Soliman et al. 2017) and weighing of settled fouling on panels. The coverage percentage of fouling that settled on panels was calculated using image software (CPCe).

\section{Statistical analysis}

Statistical differences in diameter of IZs and weight of the settled foulings were determined by one-way analysis of variance (ANOVA), using Duncan's multiple range test. Difference significances were evaluated at $P<0.05$. The $\mathrm{LC}_{50}$ values were calculated by probit analysis using EPA probit analysis program. The fouling cover percentage was estimated by dot-grid method and CPCe 4.1 program.

\section{Results}

Antifouling laboratory bioassays Antibacterial activity

The antibacterial activity results of $S$. herrmanni bioactive extracts, evaluated by disk diffusion method, are presented in Table 1. Baron and Finegold (1990) described a method for measurement of antimicrobial activity. Based on this method, among the nine bioactive extracts, $n$-hexane and ethyl acetate extracts from the body wall showed high antibacterial activity against Gram-positive bacterium $S$. aureus with inhibition zone higher than $14 \mathrm{~mm}$. 


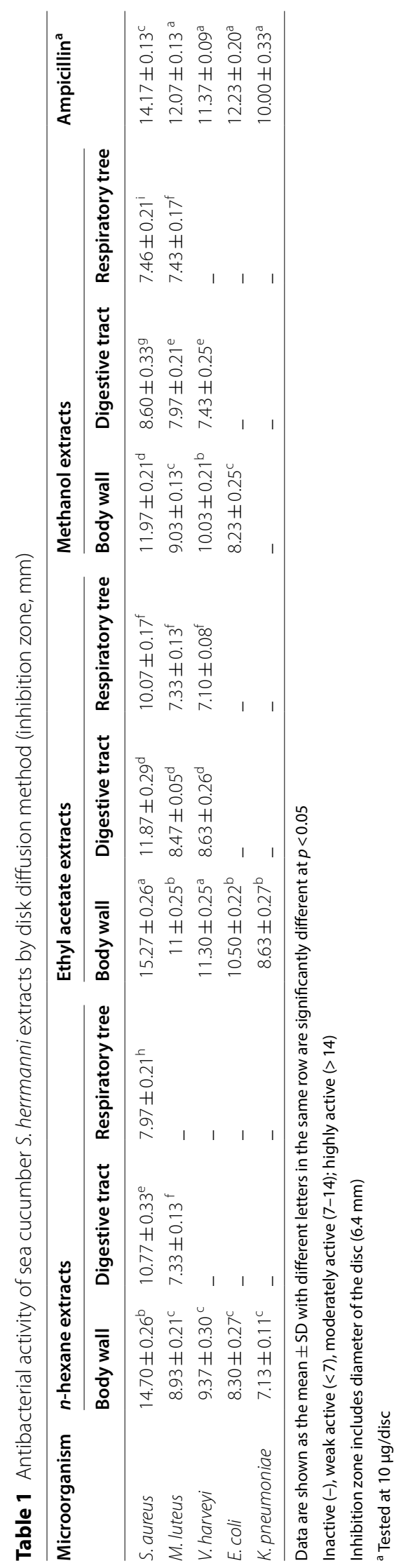


The ethyl acetate extract of the body wall exhibited significantly higher inhibition zone against $S$. aureus compared with other extracts and ampicillin (control) $(P<0.05)$. It also exhibited significantly higher inhibition zone against $V$. harveyi in comparison with other extracts $(P<0.05)$.

Among the nine $S$. herrmanni extracts, only two extracts ( $n$-hexane and ethyl acetate extracts from the body wall) showed inhibition activity (moderate) against K. pneumoniae. Therefore, $K$. pneumoniae was the most resistant tested bacteria.

Overall, only the ethyl acetate and $n$-hexane extracts of the body wall showed growth inhibition activity against all tested bacterial strains.

\section{Anti-barnacle activity}

As shown in Table 2, both ethyl acetate and methanol extracts of the body wall showed moderate toxicity against $A$. amphitrite larvae, with $\mathrm{LC}_{50}$ values of 0.061 \& $0.073 \mathrm{mg} / \mathrm{mL}$, respectively. The most pronounced cytotoxic activity against $A$. amphitrite was found in ethyl acetate extract of the body wall, which had the $\mathrm{LC}_{50}$ of $0.061 \mathrm{mg} / \mathrm{mL}$. Among the nine extracts tested, $n$-hexane extract of the respiratory tree showed the lowest cytotoxic activity against barnacle larvae, with $\mathrm{LC}_{50}$ of $0.361 \mathrm{mg} / \mathrm{mL}$.

\section{Brine shrimp cytotoxicity}

As represented in Table 3, all the nine bioactive extracts showed $\mathrm{LC}_{50}$ values more than $0.1 \mathrm{mg} / \mathrm{mL}$ against brine shrimp A. salina. This means that the toxicity of the extracts against brine shrimp (as non-target organism) is low. Also Liu et al. (2018) concluded that the isolated compounds from Nerium oleander with $\mathrm{LC}_{50}$ above $0.1 \mathrm{mg} / \mathrm{mL}$ had very low toxicity against $A$. salina. Since brine shrimp was considered as a non-target organism for any antifouling approaches and agents, having low toxicity against brine shrimp is preferable for an environmental friendly antifouling agent. If anti-brine shrimp and anti-barnacle results are compared, the tested extracts had higher $\mathrm{LC}_{50}$ values against the brine shrimp.

\section{Determination of crystallinity}

DSC analysis was used to determine the crystallinity and melting behavior of the PCL in the PCL/PLA blends at changing compositions. Figure 1 shows the DSC results of virgin PCL, PLA and PCL/PLA samples. Furthermore, the calorimetric parameters of the samples resulted from DSC thermograms are shown in Table 4. The DSC spectra of virgin PCL in cooling (Fig. 1a) exhibits an exothermic crystallization peak at around $30^{\circ} \mathrm{C}$ while virgin PLA has shown no peak. It can be seen that crystallization temperature (Tc) and degree of crystalintiy (Xc) of PCL tended to be decreased with the increase of PLA content in PCL/PLA blends. This can be attributed to the formation of defect in PCL crystalline structure and/or increase in amorphous content with the addition of PLA. The crystallization process in polymer blends can be controlled by two competing mechanisms. First, the interfacial surfaces delivered by each phase can lead to increase in the nucleation rate of macromolecules; second, the interfacial interactions between the surfaces of each phase can hinder the motions of molecules leading to the decrease of the growing rate (Luyt and Gasmi 2016). It seems that latter mechanism is dominant in crystallization process of PCL in PCL/PLA blends. In addition, the melting point $\left(\mathrm{T}_{\mathrm{m}}\right)$ of PCL crystallite and its enthalpy of melting $\left(\Delta H_{m}\right)$ obtained from the DSC heating thermogram (Fig. 1 (b)) were also shown in Table 4. The results implied that $\mathrm{T}_{\mathrm{m}}$ of PCL crystallite and its $\Delta H_{m}$ decreased with the addition of PLA.

Table 2 The toxicity effects of extracts from sea cucumber S. herrmanni against barnacle A. amphitrite larvae

\begin{tabular}{|c|c|c|c|c|c|c|c|c|c|}
\hline \multirow[t]{2}{*}{ Extract } & \multicolumn{3}{|l|}{$n$-hexane } & \multicolumn{3}{|c|}{ Ethyl acetate } & \multicolumn{3}{|l|}{ Methanol } \\
\hline & Body wall & $\begin{array}{l}\text { Digestive } \\
\text { tract }\end{array}$ & $\begin{array}{l}\text { Respiratory } \\
\text { tree }\end{array}$ & Body wall & $\begin{array}{l}\text { Digestive } \\
\text { tract }\end{array}$ & $\begin{array}{l}\text { Respiratory } \\
\text { tree }\end{array}$ & Body wall & $\begin{array}{l}\text { Digestive } \\
\text { tract }\end{array}$ & $\begin{array}{l}\text { Respiratory } \\
\text { tree }\end{array}$ \\
\hline $\mathrm{LC}_{50}(\mathrm{mg} / \mathrm{mL})$ & 0.211 & 0.296 & 0.361 & 0.061 & 0.117 & 0.148 & 0.073 & 0.179 & 0.246 \\
\hline
\end{tabular}

Table 3 Toxicity effects of extracts from sea cucumber S. hermmanni against brine shrimp A. salina larvae

\begin{tabular}{|c|c|c|c|c|c|c|c|c|c|}
\hline \multirow[t]{2}{*}{ Extract } & \multicolumn{3}{|l|}{$n$-hexane } & \multicolumn{3}{|c|}{ Ethyl acetate } & \multicolumn{3}{|l|}{ Methanol } \\
\hline & Body wall & $\begin{array}{l}\text { Digestive } \\
\text { tract }\end{array}$ & $\begin{array}{l}\text { Respiratory } \\
\text { tree }\end{array}$ & Body wall & $\begin{array}{l}\text { Digestive } \\
\text { tract }\end{array}$ & $\begin{array}{l}\text { Respiratory } \\
\text { tree }\end{array}$ & Body wall & $\begin{array}{l}\text { Digestive } \\
\text { tract }\end{array}$ & $\begin{array}{l}\text { Respiratory } \\
\text { tree }\end{array}$ \\
\hline $\mathrm{LC}_{50}(\mathrm{mg} / \mathrm{mL})$ & 0.425 & 0.591 & 0.644 & 0.136 & 0.326 & 0.398 & 0.163 & 0.375 & 0.520 \\
\hline
\end{tabular}



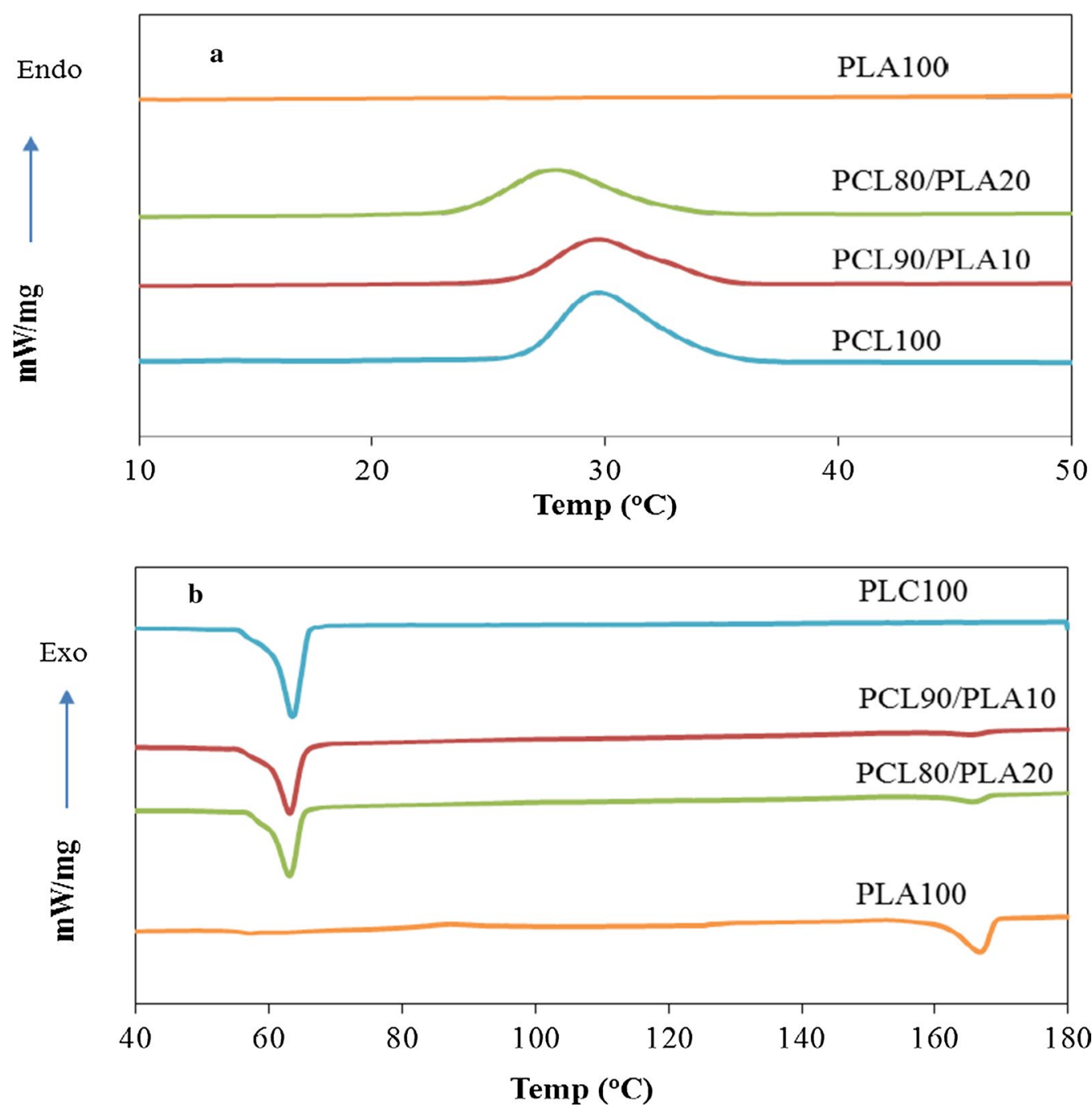

Fig. 1 DSC cooling (a) and heating (b) thermograms recorded for the PCL, PLA and PCL/PLA samples at a rate of $10^{\circ} \mathrm{C} / \mathrm{min}$

Table 4 DSC Results for PCL, PLA and their blends

\begin{tabular}{lcllll}
\hline Sample & $\boldsymbol{\Delta} \boldsymbol{H}_{\boldsymbol{c}}(\mathbf{J} / \mathbf{g})$ & $\boldsymbol{\Delta} \boldsymbol{H}_{\boldsymbol{m}}(\mathbf{J} / \mathbf{g})$ & $\mathrm{T}_{\boldsymbol{c}}\left({ }^{\circ} \mathbf{C}\right)$ & $\mathrm{T}_{\mathrm{m}}\left({ }^{\circ} \mathbf{C}\right)$ & $\boldsymbol{X}_{\boldsymbol{c}}$ \\
\hline PCL & 58.75 & -70.21 & 30 & 64 & 43.2 \\
PLA & - & -34.8 & - & 167 & - \\
PCL 90\%/PLA 10\% & $43.09^{*}$ & $-49.72^{*}$ & $29.5^{*}$ & $63^{*}$ & $39.60^{*}$ \\
PCL 80\%/PLA 20\% & $40.25^{*}$ & $-43.05^{*}$ & $28^{*}$ & $63^{*}$ & $42.28^{*}$ \\
\hline
\end{tabular}

${ }^{*}$ These values are for PCL of the blends

\section{Antifouling performance (field tests)}

The ethyl acetate extract of the body wall showed the highest in-vitro antifouling activity (including antibacterial and anti-barnacle activity); however, due to the limited ecological significance of laboratory bioassays, antifouling activity of a proper candidate should be confirmed by well-designed marine field tests (Soliman et al. 2014). Based on the laboratory results, the ethyl acetate extract of the body wall was mixed with different PCL/PLA biodegradable polymers solution and then were casted on dry PVC panels. The panels coated with polymer films were set on a frame and submerged in marine environment over three months.

Images of coated and uncoated panels over three months immersion in seawater and also their antifouling performances are shown in Figs. 2 and 3, respectively. A significant increase in fouling coverage (\%) on uncoated panel (control) was observed compared with coated panels, especially panel 5 , after one month $(P<0.05)$. Fouling coverage showed no significant difference between uncoated and panel coated with PCL (P2), at the end of month two and three $(P>0.05)$. Panel 5 (coated with PCL 
Month(s)

1
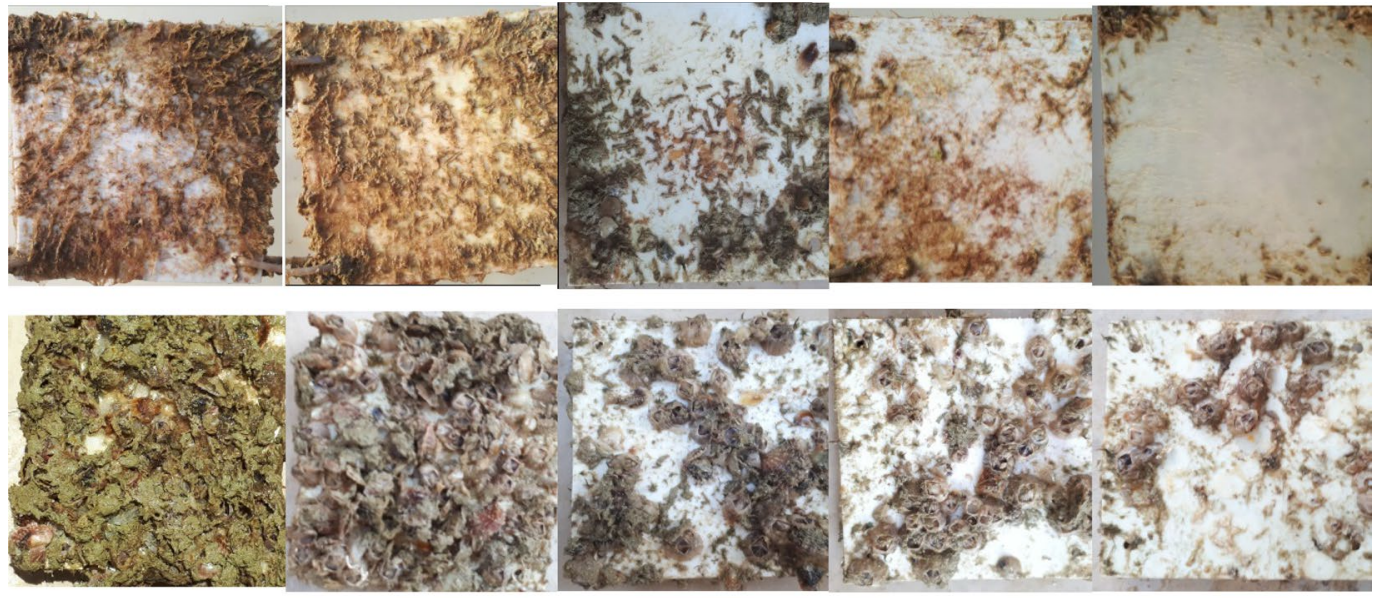

3

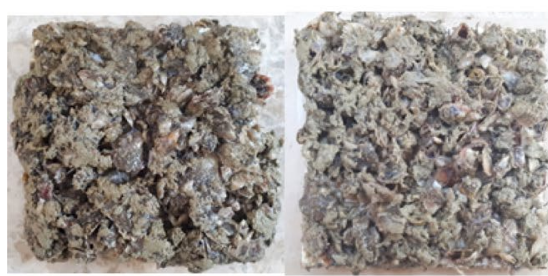

P1
P2

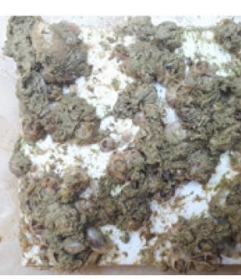

P3

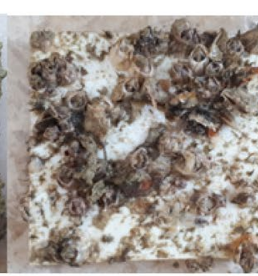

P4

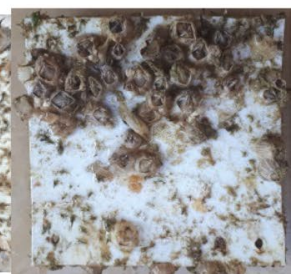

P5

Fig. 2 Panels after immersion in the seawater for three months. P1: uncoated panel (control); P2: panel coated with PCL (100\%); P3: panel coated with PCL 100\% / antifoulant 10 phr; P4: panel coated with PCL 90\% /PLA 10\% / antifoulant 10 phr; P5: panel coated with PCL 80\% /PLA 20\% / antifoulant $10 \mathrm{phr}$

80\% /PLA 20\%/natural antifoulant $10 \mathrm{phr}$ ) showed the maximum antifouling performance and the lowest fouling coverage among all the coated panels $(P<0.05)$.

Weight of fouling settled on panels is shown in Table 5. At the end of the experiment, uncoated panel (control) and PCL panel (P2) showed no significant differences in fouling weight $(P>0.05)$. Although, weight of fouling settled on uncoated panel was found to be greatly higher than the coated panels containing bioactive extract of sea cucumber $S$. hermmanni (panel 3, 4 \& 5) $(P<0.05)$. Among the coted panels, the panel 5 showed the lowest fouling weight $(P<0.05)$.

\section{Discussion}

Due to increasing concerns about toxic antifouling biocides, research is now focusing on finding and using natural eco-friendly antifoulants. Natural products from marine invertebrates like the sea cucumbers are found to be promising antifouling agents (Acevedo et al. 2013; Mert Ozupek and Cavas 2017). On the other hand, aliphatic polyesters like polycaprolactone can be used not only as a self-polishing coating but also as a release system for antifoulants due to its enzymatic or hydrolytic erosion (Gross and Kalra 2002; Nair and Laurencin 2007; Patil et al. 2014; Chen et al. 2016; Guo et al. 2016). The present study focused on the use of bioactive extracts from the sea cucumber S.herrmanni as natural antifoulants, as well as in the use of the biopolymers PCL/PLA as a self-polishing coating to make an efficient biodegradable antifouling coating.

Since the formation of bacterial biofilms on surfaces is one of the primary stages of biofouling accumulation (Gittens et al. 2013; Xie et al. 2019), antibacterial ability of a natural antifoulant candidate to prevent this accumulation is very important. In the present study, bioactive extracts from the sea cucumber showed a range of low to high antibacterial activities against the tested bacterial strains. Among the nine bioactive extracts of S.herrmanni, the ethyl acetate extract of the body wall showed the highest antibacterial activity against all the five bacterial strains. This extract also showed the highest inhibition zone $(15.27 \pm 0.26 \mathrm{~mm})$ against $S$. aureus, which was significantly higher than the standard antibiotic (ampicillin) $(P<0.05)$. These results are in accordance with a previous study carried out by Mashjoor and Yousefzadi (2017) who showed strong antibacterial 

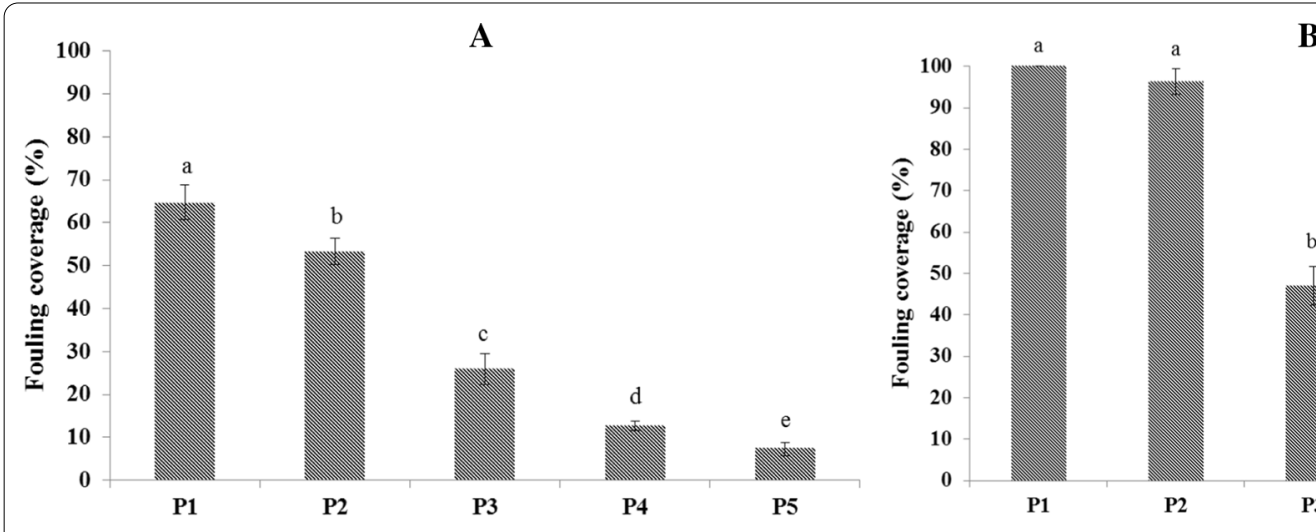

$\mathbf{B}$

C
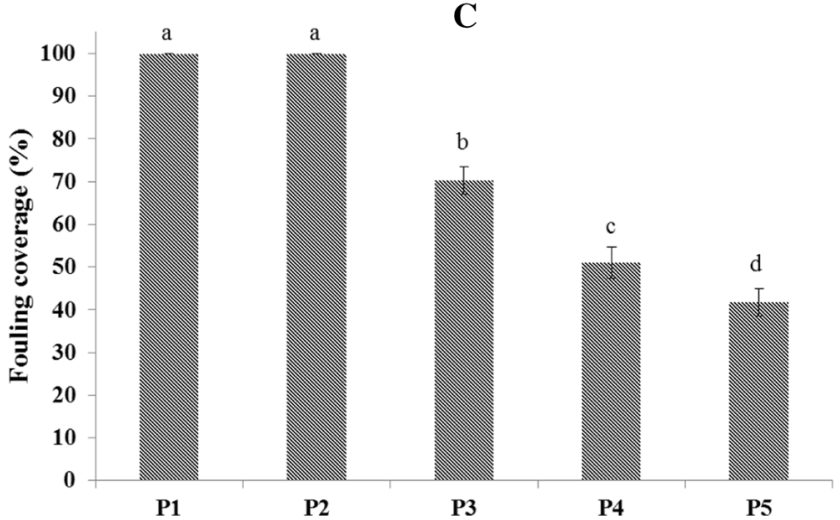

Fig. 3 Fouling coverage (\%) after immmersion in seawater for one (A), two (B) and three (C) month(s) in Bandar-e-Gorzeh, Persian Gulf. P1: uncoated panel (control); P2: panel coated with PCL (100\%); P3: panel coated with PCL 100\% / antifoulant 10 phr; P4: panel coated with PCL 90\% /PLA 10\% / antifoulant 10 phr; P5: panel coated with PCL 80\% /PLA 20\% / antifoulant 10 phr. Bars with different letters indicate a significant difference $(P<0.05)$ according to Duncan's multiple range tests

Table 5 Weight of fouling load on coated panels after immersion in the seawater for three months

\begin{tabular}{|c|c|c|c|c|c|}
\hline \\
\hline \multicolumn{6}{|l|}{ PVC panels } \\
\hline $\begin{array}{l}\text { Initial panel weight } \\
\text { (before immersion) (g) }\end{array}$ & $18.33 \pm 1.52$ & $19.33 \pm 2.08$ & $20.00 \pm 1.73$ & $19.67 \pm 2.31$ & $19.67 \pm 2.08$ \\
\hline $\begin{array}{l}\text { Final panel weight } \\
\text { (after immersion) (g) }\end{array}$ & $272.67 \pm 11.59^{\mathrm{a}}$ & $259.33 \pm 13.80^{a}$ & $172.00 \pm 13.53^{b}$ & $128.00 \pm 10.44^{c}$ & $100.67 \pm 10.12^{d}$ \\
\hline Fouling weight (g) & $254.33 \pm 12.50^{\mathrm{a}}$ & $240.00 \pm 12.17^{a}$ & $152.00 \pm 13.53^{b}$ & $108.33 \pm 9.29^{c}$ & $81.00 \pm 9.85^{d}$ \\
\hline
\end{tabular}

Data are shown as the mean \pm SD with different letters in the same row are significantly different at $p<0.05$

activity of several extracts from three different sea cucumbers. Whereas, they reported that the Staphylococcus epidermidis was the most sensitive strain against the methanolic and ethyl acetate extracts. In addition, Darya et al. (2020) reported antibacterial and antifouling activates of several extracts (especially ethyl acetate extract) from Holothuria leucospilota. They suggested that fatty acids and terpenes as the major detected compounds in the extract might be responsible for antibacterial and antifouling activities.

Barnacles are one of the most important and common macrofouling organisms (Fitridge et al. 2012; Petersen et al. 2020) which highly tend to settle down on the surfaces. The ability to prevent the settlement of barnacles on surfaces can be considered as a crucial factor for a desirable antifouling candidate. Based on 
antifouling mechanism of action, this prevention can occur through toxic or non-toxic pathways by killing or inhibition of barnacles settlement (Rittschof et al. 1992; Qian et al. 2010). In a study on anti-barnacle activity of alkyl isocyanides derived from citronellol, a natural acyclic monoterpenoid (Kitano et al. 2011), compounds with $\mathrm{LC}_{50}$ ranging from 0.021 to $0.07 \mathrm{mg} /$ $\mathrm{mL}$ were considered as compounds with moderate anti-barnacle activity. In the present study, ethyl acetate and methanol extracts of the body wall showed moderate anti-barnacle activity with LC50 values of 0.061 and $0.073 \mathrm{mg} / \mathrm{mL}$, respectively. In addition, our results showed that the toxicity of all the nine bioactive extracts were low against brine shrimp, with $\mathrm{LC}_{50}$ value of much higher than $0.1 \mathrm{mg} / \mathrm{mL}$. Also, Liu et al. (2018) concluded that the isolated compounds from Nerium oleander with $\mathrm{LC}_{50}$ above $0.1 \mathrm{mg} / \mathrm{mL}$ had very low toxicity against the brine shrimp. Since brine shrimp A. salina is considered as non-target organism for any antifouling approaches and agents, having low toxicity against brine shrimp is preferable for an environmental friendly antifouling agent.

All the results of in-vitro antifouling bioassays showed promising antifouling activities for several tested bioactive extracts, especially ethyl acetate extract of the body wall of $S$. hermmanni. Ethyl acetate is a semi-polar organic solvent and widely used to extract bioactive compounds (Asmah et al. 2020). Several studies have indicated that bioactive extracts and compounds from marine invertebrates have good antibacterial, antifungal, cell toxicity and antifouling activities (Tincu and Taylor 2004; Puentes et al. 2014; Gomes Filho et al. 2014; Datta et al. 2015; Ghadiri et al. 2018). Since polarity of the solvent plays a great role in extraction of bioactive compounds (Darya et al. 2020), and because of the economical preference of extraction compared with the purification of compounds (Liu et al. 2018), the selection of a proper solvent is very important to achieve target compounds with antifouling activity and lower price for commercial use. Consequently, ethyl acetate extracted compounds from the body wall were chosen as natural antifoulant for preparing biodegradable antifouling coatings. In line with the present study, Farjami et al. (2013), Mashjoor and Yousefzadi (2017) and Darya et al. (2020) reported antibacterial and antifouling activates from the sea cucumber semi-polar bioactive extracts. In the present study, higher antibacterial and antifouling activities were observed from the ethyl acetate extract of the body wall rather than the viscera. This could be referring to organ-specific distribution of the compounds that are responsible for these biological activities. Bahrami et al. (2018) reported that the distribution of saponins were different between the body wall and viscera of Holothuria lesson; and some highly glycosylated saponins were found only in the body wall. They reported that the examined saponins had high antifungal and antioxidant activities.

Due to the high antifouling activity of the ethyl acetate extract of the body wall, it was mixed into PCL/PLA biopolymers solution. Then, the prepared antifouling coatings were casted on PVC panels and submerged in the marine environment for three months. The results of the marine fields showed a very good antifouling performance for ethyl acetate extract as natural antifoulant added to PCL and PCL/PLA coats. Beside, adding 10\% \& $20 \%$ of PLA to the PCL coats could significantly increase antifouling performance of the experimental coats. Among the coated panels, panel coated with PCL 80\% / PLA 20\% / natural antifoulant from S. hermmanni $10 \mathrm{phr}$ had the lowest fouling weight and coverage (settled fouling) after three months. The polymers containing variety of active agents like antifoulants can be used as matrix and/or carrier in coating systems (Azemar et al. 2015, 2020; Xie et al. 2020). In antifoulling coating systems, the erosion and decomposition occurred in the polymer matrix which has degradation properties (like PCL and PLA), resulted in a self-polishing, leading to prevent the biofouling (Pan et al. 2020; Azemar et al. 2020). Furthermore, the higher rate in the controlled release of antifoulant from the polymer matrix of antifouling coatings during the time is desired. The degradable polymers based on PCL and/or PLA matrix which decompose continuously in environments like the seawater can provide the situation in which the antifoulant is released in a controlled manner at higher rate, compared with the undegradable polymers (Yao et al. 2014; Chiang et al. 2020). It seems that the hydrolytic degradation rate in the PCL/ PLA coating samples increased with increasing the PLA content as a result of higher hydrolytic degradation rate of PLA than that of PCL due to its lower hydrophobicity (Kutikov and Song 2015). This leads to the higher self-polishing properties and higher releasing rate of antifoulant in the prepared coating samples containing higher content of PLA. On the other hand, permeation of materials such as water, antifoulant and/or impurities through amorphous phase of polymers is easier than that of crystal phase as a consequence of lower compactness (Chen et al. 2016). In addition, it can be expected that the degradation process which facilitates the release of materials can be enhanced with increasing content of amorphous phase in the samples. DSC results showed that the amorphous phase of PCL increased with the addition of PLA and therefore it can more intensify the release of antifoulant from PCL/PLA coating samples. These can be considered as the causes of the highest antifouling 
properties of PCL $80 \%$ /PLA $20 \%$ coating containing 10 phr of natural antifoulant from S. hermmanni.

Our findings suggest that some bioactive extracts, especially semi polar solvent-extractable compounds, from the sea cucumber S.herrmanni might have promising antibacterial and antifouling activities and can be used for environmentally friendly antifouling proposes. We also observed that the antifouling and anti-settling performance of the biopolymer (PCL)/ the natural antifoulant coat could be improved by the addition of PLA. This can be attributed to the enhanced self-renewing properties in combination with the easier releasing of the natural antifoulant.

\section{Acknowledgements}

Not applicable.

\section{Authors' contributions}

MD: Investigation, Data curation, Formal analysis, Writing —original draft, Writing — review \& editing. MHA: Methodology, Formal analysis, Writing—original draft, Writing—review \& editing. MY \& MMS: Supervision, Conceptualization, Methodology, Writing — review \& editing. IS \& MZ: Writing —review \& editing.

\section{Funding}

This work was supported by grants from the University of Guilan.

\section{Data availability}

The datasets generated during and/or analysed during the current study are available from the corresponding author on reasonable request.

\section{Declarations}

\section{Ethics approval and consent to participate}

This paper does not contain any studies with human participants or vertebrate animals performed by any of the authors.

\section{Consent for publication}

Not applicable.

\section{Competing interests}

The authors declare that they have no conflict of interests.

\section{Author details \\ 'Department of Fisheries, Faculty of Natural Resources, University of Guilan, Sowmeh Sara, Iran. ${ }^{2}$ Department of Chemical Engineering, Faculty of Chemi- cal Engineering, University of Hormozagn, Bandar-Abbas, Iran. ${ }^{3}$ Department of Biology, Faculty of Science, University of Qom, Qom, Iran. ${ }^{4}$ Department of Fisheries, Faculty of Marine Science and Technology, University of Hormoz- gan, Bandar Abbas, Iran. ${ }^{5}$ Department Of Chemistry, Faculty of Basic Science, University Of Hormozgan, Bandar Abbas, Iran.}

Received: 13 December 2021 Accepted: 3 February 2022

Published online: 27 February 2022

\section{References}

Acevedo MS, Puentes C, Carreño K, León JG, Stupak M, García M, Pérez M, Blustein G (2013) Antifouling paints based on marine natural products from Colombian Caribbean. Int Biodeterior Biodegrad 83:97-104. https:// doi.org/10.1016/j.ibiod.2013.05.002

Aminin D, Menchinskaya E, Pisliagin E, Silchenko A, Avilov S, Kalinin V (2015) Anticancer activity of sea cucumber triterpene glycosides. Mar Drugs 13:1202-1223. https://doi.org/10.3390/md13031202

Asmah N, Suniarti D, Margono A, Mas'ud ZA, Bachtiar E (2020) Identification of active compounds in ethyl acetate, chloroform, and $\mathrm{N}$-hexane extracts from peels of Citrus aurantifolia from Maribaya, West Java, Indonesia. J Adv Pharm Technol Res 11:107-112. https://doi.org/10.4103/japtr.JAPTR_ 177_19

Azemar F, Faÿ F, Réhel K, Linossier I (2015) Development of hybrid antifouling paints. Prog Org Coatings 87:10-19. https://doi.org/10.1016/j.porgcoat. 2015.04.007

Azemar F, Faÿ F, Réhel K, Linossier I (2020) Ecofriendly silicon-poly(lactic acid) hybrid antifouling coatings. Prog Org Coatings 148:105841. https://doi.org/10.1016/.jporgcoat.2020.105841

Bahrami Y, Zhang W, Franco C MM (2018) Distribution of saponins in the sea cucumber holothuria lessoni; the body wall versus the viscera, and their biological activities. Mar Drugs 16:1-30. https://doi.org/10.3390/ md16110423

Bao VWW, Leung KMY, Kwok KWH, Zhang AQ, Lui GCS (2008) Synergistic toxic effects of zinc pyrithione and copper to three marine species: implications on setting appropriate water quality criteria. Mar Pollut Bull 57:616-623. https://doi.org/10.1016/j.marpolbul.2008.03.041

Baron E, Finegold S (1990) Methods for testing anti-microbial effectiveness. In: Stephanie M (ed) Diagnostic microbiology. Mosboy, Baltimore MD, pp 171-194

Chen S, Ma C, Zhang G (2016) Biodegradable polymers for marine antibiofouling: Poly( $\varepsilon$-caprolactone)/poly(butylene succinate) blend as controlled release system of organic antifoulant. Polym (united Kingdom) 90:215-221. https://doi.org/10.1016/j.polymer.2016.03.017

Chiang HY, Pan J, Ma C, Qian P-Y (2020) Combining a bio-based polymer and a natural antifoulant into an eco-friendly antifouling coating. Biofouling 36:200-209. https://doi.org/10.1080/08927014.2020.1749270

Darya M, Sajjadi MM, Yousefzadi M, Sourinejad I, Zarei M (2020) Antifouling and antibacterial activities of bioactive extracts from different organs of the sea cucumber Holothuria leucospilota. Helgol Mar Res 74:1-13. https://doi.org/10.1186/s10152-020-0536-8

Datta D, Nath Talapatra S, Swarnakar S (2015) Bioactive compounds from marine invertebrates for potential medicines-an overview. Int Lett Nat Sci 34:42-61. https://doi.org/10.18052/www.scipress.com/ILNS. 34.42

Farjami B, Nematollahi MA, Moradi Y, Irajian G, Nazemi M, Ardebili A, Pournajaf A (2013) Antibacterial activity of the sea cucumber Holothuria leucospilota. Int J Mol Clin Microbiol 3:225-230

Faÿ F, Linossier I, Langlois V, Renard E, Vallée-Réhel K (2006) Degradation and controlled release behavior $\varepsilon$-caprolactone copolymers in biodegradable antifouling coatings. Biomacromol 7:851-857. https://doi.org/10. 1021/bm0509669

Fitridge I, Dempster T, Guenther J, de Nys R (2012) The impact and control of biofouling in marine aquaculture: a review. Biofouling 28:649-669. https://doi.org/10.1080/08927014.2012.700478

da Gama BAP, Carvalho AGV, Weidner K, Soares AR, Coutinho R, Fleury BG, Teixeira VL, Pereira RC (2008) Antifouling activity of natural products from Brazilian seaweeds. Bot Mar 51:191-202. https://doi.org/10.1515/ BOT.2008.027

Ghadiri M, Kazemi S, Heidari B, Rassa M (2018) Bioactivity of aqueous and organic extracts of sea cucumber Holothuria leucospilota (Brandt 1835) on pathogenic Candida and Streptococci. Int Aquat Res 10:31-43. https://doi.org/10.1007/s40071-017-0186-x

Gittens JE, Smith TJ, Suleiman R, Akid R (2013) Current and emerging environmentally-friendly systems for fouling control in the marine environment. Biotechnol Adv 31:1738-1753. https://doi.org/10.1016/j. biotechadv.2013.09.002

Gomes Filho S, Cardoso J, Anaya K, Silva do Nascimento E, de Lacerda J, Mioso R, Santi Gadelha T, de Almeida Gadelha C (2014) Marine sponge lectins: actual status on properties and biological activities. Molecules 20:348-357. https://doi.org/10.3390/molecules20010348

Gross RA, Kalra B (2002) Biodegradable polymers for the environment. Science (80-) 297:803-807

Guo Y, Yang K, Zuo X, Xue Y, Marmorat C, Liu Y, Chang C-C, Rafailovich MH (2016) Effects of clay platelets and natural nanotubes on mechanical properties and gas permeability of Poly (lactic acid) nanocomposites. Polymer (guildf) 83:246-259. https://doi.org/10.1016/j.polymer.2015. 12.012

Han H, Yi YH, Li L, Liu BS, La MP, Zhang HW (2009) Antifungal active triterpene glycosides from sea cucumber Holothuria scabra. Acta Pharm Sin 44:620-624 
lyapparaj P, Revathi P, Ramasubburayan R, Prakash S, Anantharaman P, Immanuel G, Palavesam A (2013) Antifouling activity of the methanolic extract of Syringodium isoetifolium, and its toxicity relative to tributyltin on the ovarian development of brown mussel Perna indica. Ecotoxicol Environ Saf 89:231-238. https://doi.org/10.1016/j.ecoenv.2012.12.001

Jerabek AS, Wall KR, Stallings CD (2016) A practical application of reduced-copper antifouling paint in marine biological research. PeerJ 4:e2213. https:// doi.org/10.7717/peerj.2213

Jun DC, Dan QF, Zhi WY, Zhan CW, Qiu Y, Yi ML (2008) Antifouling metabolites from the mangrove plant Ceriops tagal. Molecules 13:212-219. https://doi. org/10.3390/molecules13020212

Kamtsikakis A, Kavetsou E, Chronaki K, Kiosidou E, Pavlatou E, Karana A Papaspyrides C, Detsi A, Karantonis A, Vouyiouka S (2017) Encapsulation of antifouling organic biocides in poly(Lactic acid) nanoparticles. Bioengineering. https://doi.org/10.3390/bioengineering4040081

Kitano Y, Akima C, Yoshimura E, Nogata Y (2011) Anti-barnacle activity of novel simple alkyl isocyanides derived from citronellol. Biofouling 27:201-205. https://doi.org/10.1080/08927014.2011.553282

Kutikov AB, Song J (2015) Biodegradable PEG-based amphiphilic block copolymers for tissue engineering applications. ACS Biomater Sci Eng 1:463-480. https://doi.org/10.1021/acsbiomaterials.5b00122

Liu H, Chen SY, Guo JY, Su P, Qiu YK, Ke CH, Feng DQ (2018) Effective natural antifouling compounds from the plant Nerium oleander and testing. Int Biodeterior Biodegrad 127:170-177. https://doi.org/10.1016/j.ibiod.2017. 11.022

Luyt AS, Gasmi S (2016) Influence of blending and blend morphology on the thermal properties and crystallization behaviour of PLA and PCL in PLA/PCL blends. J Mater Sci 51:4670-4681. https://doi.org/10.1007/ s10853-016-9784-z

Ma C, Zhang W, Zhang G, Qian PY (2017) Environmentally friendly antifouling coatings based on biodegradable polymer and natural antifoulant. ACS Sustain Chem Eng 5:6304-6309. https://doi.org/10.1021/acssuschemeng. $7 \mathrm{~b} 01385$

Mamelona J, Pelletier É, Girard-Lalancette K, Legault J, Karboune S, Kermasha S (2007) Quantification of phenolic contents and antioxidant capacity of Atlantic sea cucumber, Cucumaria frondosa. Food Chem 104:1040-1047. https://doi.org/10.1016/j.foodchem.2007.01.016

Maruthanayagam V, Nagarajan M, Sundararaman M (2013) Cytotoxicity assessment of cultivable marine cyanobacterial extracts in Artemia salina (brine shrimp) larvae and cancer cell lines. Toxin Rev 32:1-9. https://doi.org/10. 3109/15569543.2012.754772

Mashjoor S, Yousefzadi M (2017) Holothurians antifungal and antibacterial activity to human pathogens in the Persian Gulf. J Mycol Med 27:46-56. https:// doi.org/10.1016/j.mycmed.2016.08.008

Mert Ozupek N, Cavas L (2017) Triterpene glycosides associated antifouling activity from Holothuria tubulosa and H. polii. Reg Stud Mar Sci 13:32-41. https://doi.org/10.1016/j.rsma.2017.04.003

Nair LS, Laurencin CT (2007) Biodegradable polymers as biomaterials. Prog Polym Sci 32:762-798. https://doi.org/10.1016/j.progpolymsci.2007.05.017

Palanichamy S, Subramanian G (2017) Antifouling properties of marine bacteriocin incorporated epoxy based paint. Prog Org Coatings 103:33-39. https://doi.org/10.1016/j.porgcoat.2016.11.020

Pan J, Xie Q, Chiang H, Peng Q, Qian P-Y, Ma C, Zhang G (2020) "From the nature for the nature": an eco-friendly antifouling coating consisting of poly(lactic acid)-based polyurethane and natural antifoulant. ACS Sustain Chem Eng 8:1671-1678. https://doi.org/10.1021/acssuschemeng.9b06917

Patil N, Kelsey J, Fischer J, Grady B, White JL (2014) Creating polymer templates and their use in the in-situ synthesis of biodegradable composite networks. Polymer (guildf) 55:2332-2339. https://doi.org/10.1016/j.polymer.2014.03. 060

Petersen DS, Schultz M, Gorb SN, Heepe L (2020) A systematic investigation into the effect of fibrillar microstructures on the settlement and attachment strength of the bay barnacle Balanus improvisus under natural conditions. Appl Phys A 126:1-11. https://doi.org/10.1007/s00339-020-03870-2

Piazza V, Roussis V, Garaventa F, Greco G, Smyrniotopoulos V, Vagias C, Faimali M (2011) Terpenes from the Red Alga Sphaerococcus coronopifolius Inhibit the Settlement of Barnacles. Mar Biotechnol 13:764-772. https://doi.org/10. 1007/s10126-010-9337-4

Puentes C, Carreño K, Santos-Acevedo M, Gomez-León J, García M, Pérez M, Stupak M, Blustein G (2014) Anti-fouling paints based on extracts of marine organisms from the Colombian Caribbean. Sh Sci Technol 8:75-90. https:// doi.org/10.25043/19098642.105

Qian P-Y, Xu Y, Fusetani N (2010) Natural products as antifouling compounds: recent progress and future perspectives. Biofouling 26:223-234. https://doi. org/10.1080/08927010903470815

Qian PY, Li Z, Xu Y, Li Y, Fusetani N (2015) Mini-review: Marine natural products and their synthetic analogs as antifouling compounds: 2009-2014. Biofouling 31:101-122. https://doi.org/10.1080/08927014.2014.997226

Rezgui F, Swistek M, Hiver JM, G'Sell C, Sadoun T (2005) Deformation and damage upon stretching of degradable polymers (PLA and PCL). Polymer (guildf) 46:7370-7385. https://doi.org/10.1016/j.polymer.2005.03.116

Rittschof D, Clare AS, Gerhart DJ, Mary SA, Bonaventura J (1992) Barnacle in vitro assays for biologically active substances: Toxicity and Settlement inhibition assays using mass cultured Balanus amphitrite amphitrite darwin. Biofouling 6:115-122. https://doi.org/10.1080/08927019209386217

Silva ER, Tulcidas AV, Ferreira O, Bayón R, Igartua A, Mendoza G, Mergulhão FJM Faria SI, Gomes LC, Carvalho S, Bordado JCM (2021) Assessment of the environmental compatibility and antifouling performance of an innovative biocidal and foul-release multifunctional marine coating. Environ Res. https://doi.org/10.1016/j.envres.2021.111219

Soliman YA, Mohamed AS, NaserGomaa M (2014) Antifouling activity of crude extracts isolated from two Red Sea puffer fishes. Egypt J Aquat Res 40:1-7. https://doi.org/10.1016/j.ejar.2014.01.002

Soliman YAA, Brahim AM, Moustafa AH, Hamed MAF (2017) Antifouling evaluation of extracts from Red Sea soft corals against primary biofilm and biofouling. Asian Pac J Trop Biomed 7:991-997. https://doi.org/10.1016/j. apjtb.2017.09.016

Suresh M, lyapparaj P, Anantharaman P (2016) Antifouling activity of lipidic metabolites derived from Padina tetrastromatica. Appl Biochem Biotechnol 179:805-818. https://doi.org/10.1007/s12010-016-2032-9

Thouvenin M, Langlois V, Briandet R, Langlois JY, Guerin PH, Peron JJ, Haras D, Vallee-Rehel K (2003) Study of erodable paint properties involved in antifouling activity. Biofouling. https://doi.org/10.1080/08927014.2003. 10382980

Tian F, Zhang X, Tong Y, Yi Y, Zhang S, Li L, Sun P, Lin L, Ding J (2005) PE, a new sulfated saponin from sea cucumber, exhibits anti-angiogenic and antitumor activities in vitro and in vivo. Cancer Biol Ther 4:874-882. https://doi. org/10.4161/cbt.4.8.1917

Tincu JA, Taylor SW (2004) Antimicrobial peptides from marine invertebrates. Antimicrob Agents Chemother 48:3645-3654. https://doi.org/10.1128/ AAC.48.10.3645-3654.2004

Vanden Berghe DA, Vlietinck AJ (1991) Screening methods for antibacterial and antiviral agents from higher plants. In: Dey P, Harbone J (eds) Methods in plant biochemistry. Academic press, London, pp 47-69

Venkatnarayanan S, Murthy PS, Kirubagaran R, Venugopalan VP (2016) Effect of chlorination on barnacle larval stages: implications for biofouling control and environmental impact. Int Biodeterior Biodegradation 109:141-149. https://doi.org/10.1016/j.ibiod.2016.01.011

Xie Q, Pan J, Ma C, Zhang G (2019) Dynamic surface antifouling: mechanism and systems. Soft Matter 15:1087-1107. https://doi.org/10.1039/C8SM01853G

Xie C, Guo H, Zhao W, Zhang L (2020) Environmentally friendly marine antifouling coating based on a synergistic strategy. Langmuir 36:2396-2402. https://doi.org/10.1021/acs.langmuir.9b03764

Xu W, Ma C, Ma J, Gan T, Zhang G (2014) Marine biofouling resistance of polyurethane with biodegradation and hydrolyzation. ACS Appl Mater Interfaces 6:4017-4024. https://doi.org/10.1021/am4054578

Yamada H (2007) Behaviour, occurence, and aquatic toxicity of new antifouling biocides and preliminary assessment of risk to aquatic ecosystems. Bull Fish Res Agency 21:31-45

Yao J, Chen S, Ma C, Zhang G (2014) Marine anti-biofouling system with poly( $\varepsilon$ caprolactone)/clay composite as carrier of organic antifoulant. J Mater Chem B 2:5100-5106. https://doi.org/10.1039/c4tb00545g

\section{Publisher's Note}

Springer Nature remains neutral with regard to jurisdictional claims in published maps and institutional affiliations. 